\title{
Strategies for Appropriate Patient-centered Care to Decrease the Nationwide Cost of Cancers in Korea
}

\author{
Jong-Myon Bae \\ Department of Preventive Medicine, Jeju National University School of Medicine, Jeju, Korea
}

In terms of years of life lost to premature mortality, cancer imposes the highest burden in Korea. In order to reduce the burden of cancer, the Korean government has implemented cancer control programs aiming to reduce cancer incidence, to increase survival rates, and to decrease cancer mortality. However, these programs may paradoxically increase the cost burden. For examples, a cancer screening program for early detection could bring about over-diagnosis and over-treatment, and supplying medical services in a paternalistic manner could lead to defensive medicine or futile care. As a practical measure to reduce the cost burden of cancer, appropriate cancer care should be established. Ensuring appropriateness requires patient-doctor communication to ensure that utility values are shared and that autonomous decisions are made regarding medical services. Thus, strategies for reducing the cost burden of cancer through ensuring appropriate patient-centered care include introducing value-based medicine, conducting cost-utility studies, and developing patient decision aids.

Key words: Tumor burden, Cost of illness, Medical practice, Quality of health care, Practice valuation and purchase, Decision support techniques

\section{INTRODUCTION}

Measurements of the diseases burden and predictions of trends form the basis for decision-making and the implementation of public health policies, thereby promoting public health in any country [1]. Worldwide, countries are feeling the pressure of the soaring burden of medical care [2]. Increasingly, more countries are using the diseases burden as an important benchmark to decide how to effectively distribute limited

Received: April 26, 2017 Accepted: June 16, 2017

Corresponding author: Jong-Myon Bae, MD, PhD

102 Jejudaehak-ro, Jeju 63241, Korea

Tel: +82-64-755-5567, Fax: +82-64-702-2687

E-mail: jmbae@cheju.ac.kr

This is an Open Access article distributed under the terms of the Creative Commons Attribution Non-Commercial License (http://creativecommons.org/licenses/bync/4.0/) which permits unrestricted non-commercial use, distribution, and reproduction in any medium, provided the original work is properly cited. medical resources [3].

So far, approaches to measure the diseases burden have principally focused on using (1) conventional epidemiological indices, (2) measuring the cost burden, and (3) calculating indicators of health-related quality of life (HRQoL) [4]. Of these, with respect to HRQoL, the World Health Organization spearheaded the development of an index known as the disabilityadjusted life year (DALY) and continues to conduct research on the global burden of disease [5].

In Korea, in terms of DALYs, cancer had the highest disease burden in 2002 [6]; a decade later, this changed to endocrine diseases in 2012 [7]. However, when the years of life lost to premature mortality are used as the index of disease burden, cancer remained the disease with the highest burden in 2012 [7]. This shows that our interpretation of disease burden may be affected by which indices are used; thus, the use of an alternative index such as the mortality-to-incidence ratio (MIR) 
Table 1. Indices of the overall cancer burden between 2002 and 2012 in Korea'

\begin{tabular}{lcc}
\hline & $\mathbf{2 0 0 2}$ & $\mathbf{2 0 1 2}$ \\
\hline DALY [3,5] & 1525 & 2261 \\
Incidence [9] & 229.8 & 323.3 \\
Mortality [10] & 149.0 & 131.3 \\
\hline
\end{tabular}

DALY, disability-adjusted life years.

'DALY: per 100000 population; Age-adjusted Incidence and mortality: per 100000 population.

has been suggested [8].

Thus, the policies developed to reduce the cancer burden can be summarized as aiming to reduce cancer incidence, to improve the cure rates in cancer patients, and to decrease cancer-related mortality [8]. However, when we assessed the changes in the cancer incidence and mortality rate, and DALYs across a decade, from 2002 to 2012, we found that in contrast to the decreasing mortality rate, the cancer incidence and DALYs increased, showing that there is a need to re-evaluate the cancer burden indices (Table 1). For instance, the national cancer screening programs that were started in order to decrease the cancer burden may paradoxically increase the cost burden of cancer by increasing cancer prevalence [11-14]. Thus, the cost burden would be considered as another index of cancer burden [13].

The purpose of this paper was to assess whether efforts to reduce the cancer burden are having an effect not only in terms of impacting the cancer-burden-related indices, but also in terms of reducing the cost burden of cancer. And then, we would propose strategies about how to minimize the cost of cancer by implementing adequate cancer treatments centered on the patients who are customers of medical services.

\section{OUTCOMES OF CANCER BURDEN REDUCTION POLICIES BASED ON CANCER- RELATED STATISTICAL INDICES}

\section{Decreasing Cancer Incidence}

Cancer prevention is by far the most effective approach to decrease the cancer burden [15]. Computing the attributable fractions of the risk factors [16] and, then based on these results, developing primary cancer prevention strategies to suppress risk effects should be conducted preferentially and continuously [17]. The fact that the cancer incidence in Koreans has decreased since 2012 is a promising marker, which also reflects an actual reduction in the national burden of cancer [9].

\section{Improving Cure Rates of Cancer Treatment}

Improving the cure rates of cancer treatment in those who already have cancer brings on a reduced burden of cancer. Strategies to increase the cure rate include (1) making early diagnoses and (2) providing more effective medical services.

In Korea, the first of these strategies was the National Cancer Screening Program (NCSP) established in 1999. Till 2016, the program has expanded its list of cancers screened to include the 5 major primary cancers - stomach, liver, colorectal, breast, and uterine cervical-in adults [18]. The findings that all these cancers, except breast cancer, showed a decreasing trend in incidence from 2012 to 2014 [9] and that the total cancer mortality, which had increased between 1983 and 2002, showed a decrease between 2002 and 2007 can be explained as positive outcomes of the NCSP [10]. Nonetheless, further studies containing a cost analysis of the NCSP are required to assess its outcomes more accurately.

Meanwhile, the fact that the incidence rate of breast cancer, which is included as an item in the NCSP, has consistently increased should be considered cautiously with a controversy of the over-diagnosis of the cancer screening $[19,20]$. Because breast cancer along with thyroid cancer, prostate cancer, and renal cancer is the representative cancer that are over-diagnosed $[21,22]$. Over-diagnosis in turn causes over-treatment and the abuse of medical services; thus, the result of efforts for early diagnosis could lead to an increase in the cancer burden, counterintuitively $[11,23]$. For these reasons, the inclusion of breast cancer in the current NCSP should be re-evaluated [24]. Whereas, only screening for cancers whose burden has been shown to be minimized through early diagnosis may lead to a net reduction in the cancer burden [10].

The second strategy is to provide more effective medical services. Recently, much work in this area has involved providing personalized medicine or precision medicine, such as individualized chemotherapy tailored to the genetic make-up of the patient's cancer [25]. Despite the increasing cost of treating cancer with such improvements in medical technology, the cost-effectiveness of these treatments in reality is scarcely substantial enough to be of any real use for evidence-based decision-making $[2,14]$. In other words, since a greater emphasis is placed on the efficacy of treatment than on the economic burden, the cost burden of cancers with respect to cancer treatment is increasing $[11,12]$.

Moreover, higher cure rates lead to higher cancer prevalence, which may increase the years lived with disability and in 
turn contribute to the increased cancer burden [26]. Thus, measures focused on improving cure rates can lead to absolute increases in the cost burden of all cancers, excluding cancer screening program that are known as effective.

\section{Decreasing Cancer Mortality}

Whether cancer treatment was unsuccessful or was successful but the possibility of recurrence remains, decreasing early mortality to improve survival rates in cancer patients is an important part of reducing the burden of cancer. However, by endeavoring to improve the survival rates of cancer patients, we may be promoting defensive medicine or futile death-prolonging treatments, counterintuitively.

Defensive medicine refers to non-essential medical services performed to counteract medical malpractice [27]; thus, such practices can in turn entail costly medical fees, expand the medical insurance budget, and subsequently increase the burden of cancer $[12,27]$. In terminal cancer patients, death-prolonging treatment may also incur unnecessary expenses to delay death [28].

\section{SUGGESTIONS FOR CUTTING THE COST BURDEN OF CANCERS: ACHIEVING APPROPRIATE PATIENT-CENTERED CARE}

We evaluated how measures, except those aimed at decreasing incidence by controlling risk factors, aimed at reducing the cancer burden by improving 3 indices-the incidence rate, cure rate, and mortality rate-may paradoxically lead to increased costs of cancer treatment and thereby increase the actual cancer burden. Conversely, given that screening for only cancers that can be effectively controlled through early diagnosis leads to real reductions in the cancer burden, a 3-way concerted effort by patients, physicians, and policy-makers should be made to control the cancer burden through the 2 indices above - the cure rate and the mortality rate $[29,30]$.

In particular, more efficient and effective care should be needed against the apparent increment in the economic burden of cancer that reflect the escalating cost of cancer treatments. This calls for a realization of appropriateness of medical services [29]. To practically drive the appropriateness of care, Brook [29] suggested that both patients and physicians must share their values and allow for patient autonomy in decisionmaking.

The following milestones should be met if Brook's recom- mendations are to be followed: (1) a horizontal patient-physician relationship in terms of communication; (2) closing the patient-physician values gap by using various communication tools to allow patients to understand their physicians; and (3) fostering a proactive and autonomous decision-making environment for patients to choose the kind of medical services they receive [30-33]. Employing these practices will prevent us falling into the inconsistency of increasing the cost burden of cancers through mechanisms such as defensive medicine and death-prolonging treatment while aiming to decrease the cost burden of cancers. To achieve the ideal appropriateness of care, the following operational measures for these three milestones were proposed.

\section{Building Competency in Patient-physician Communication}

Patient-physician communication is one of the most important aspects of cancer treatment [34]. Because it involves informing cancer patients of their final diagnosis as well as discussing the financial implications of having cancer with them [35]. Thus, physicians must utilize action guidelines to build a positive relationship with patients [36]. To this end, a protocol known as SPIKE\$ was developed [37], so that it need to be adapted and contextualized to the Korean medical environment.

Studies have found that younger patients, female patients, and patients with higher educational levels tended to demand a greater level of patient-physician communication [34]. These finding suggests that an educational curriculum should be developed that teaches physicians ways to deal with patients from diverse socio-demographic backgrounds [38].

Physicians should communicate to patients what is set out in the clinical practice guidelines (CPGs), which are developed according to the best evidence [33]. However, CPGs are not easily applicable to real-life contexts because there may not be enough scientific evidences or due to wide variation in the medical services that individual patients expect $[31,38]$. Further research may be done in cases of insufficient evidence. However, when individual demands differ, the next step should be to determine patient preferences, after which physicians should be able to explain the relationships between the costs of various treatments and the benefit of their outcomes [12]. Underestimating the importance of this step leads to the widespread use of defensive medicine and unnecessary death-prolonging treatment $[27,28]$. 


\section{Development of a Values Assessment Tool to} Determine Patient Preferences

Incorporating the preferences of patients in decision-making in medicine is a way of implementing value-based medicine [31]. Patient preferences are closely linked to utility, which influences decision-making processes through an evaluation of the estimated gain and loss [39].

The time trade-off technique is the most widely used indicator for measuring the utility value in patients because it is easy for the lay individual to understand and gives reproducible results [40]. An adapted scale, based on the time-trade-off technique, must be developed for a cost-utility analysis appropriate to the Korean context to be conducted [31]. This would allow cancer patients to make choices that maximize the costto-utility ratio with respect to cancer treatment, leading to real reductions in the cost burden of cancers [41].

\section{Development of a Tool That Assists Autonomous Decision-making in Patients}

For cancer patients, as the consumers of medical services, to be completely autonomous in their decision making, the provider of these services, or the physicians, must provide them with sufficient explanations based on the best evidence; only then can patients make an informed choice regarding their preferred mode of treatment [38].

Patient decision aids (PDAs) are currently under development. These PDAs are expected to better inform patients of their situation, to allow them to make an objective assessment of their preferences, and to promote patient autonomy when deciding the kind of care they wish to receive $[32,42]$. For instance, a PDA has been developed that enables patients to critically evaluate whether they will undergo screening for prostate cancer, a cancer often associated with over-diagnosis [43]; interestingly, the application of this PDA has lowered the rate of screening by $13 \%$ [44]. As such, autonomous decisions by medical consumers using PDAs will help in the long run to reduce the wastage of medical resources through practices such as defensive medicine $[45,46]$ and will improve the quality of public health care $[38,47]$.

\section{CONCLUSION}

Thus, the following measures would ensure that appropriate cancer care is established: the development of guidelines that build patient-physician communication competence in physi- cians; a scale to measure patients' utility value; and finally, PDAs, which encourage patient autonomy in decision-making on the basis of the best evidences and utility values. Through such measures, not only the patients' cost burden of cancers but also that of the country as a whole can be reduced.

\section{ACKNOWLEDGEMENTS}

This research was funded by the Jeju National University Research Excellence Foundation in 2017.

\section{CONFLICT OF INTEREST}

The author has no conflicts of interest associated with the material presented in this paper.

\section{SUPPLEMENTAL MATERIAL}

Supplemental material (Korean version) is available at http://www.jpmph.org/.

\section{ORCID}

Jong-Myon Bae http://orcid.org/0000-0003-3080-7852

\section{REFERENCES}

1. Williams A. Calculating the global burden of disease: time for a strategic reappraisal? Health Econ 1999;8(1):1-8.

2. Meropol NJ, Schulman KA. Cost of cancer care: issues and implications. J Clin Oncol 2007;25(2):180-186.

3. Yoon SJ, Lee H, Shin Y, Kim YI, Kim CY, Chang H. Estimation of the burden of major cancers in Korea. J Korean Med Sci 2002; 17(5):604-610.

4. Yoon SJ, Bae SC. Current scope and perspective of burden of disease study based on health related quality of life. J Korean Med Assoc 2004;47(7):600-602 (Korean).

5. Gong YH, Yoon SJ, Jo MW, Kim A, Kim YA, Yoon J, et al. The burden of cancer in Korea during 2012: findings from a prevalence-based approach. J Korean Med Sci 2016;31 Suppl 2: S168-S177.

6. Yoon SJ, Bae SC, Lee SI, Chang H, Jo HS, Sung JH, et al. Measuring the burden of disease in Korea. J Korean Med Sci 2007; 22(3):518-523.

7. Yoon J, Oh IH, Seo H, Kim EJ, Gong YH, Ock M, et al. Disability- 
adjusted life years for 313 diseases and injuries: the 2012 Korean Burden of Disease Study. J Korean Med Sci 2016;31 Suppl 2:S146-S157.

8. Soerjomataram I, Lortet-Tieulent J, Ferlay J, Forman D, Mathers C, Parkin DM, et al. Estimating and validating disability-adjusted life years at the global level: a methodological framework for cancer. BMC Med Res Methodol 2012;12:125.

9. Jung KW, Won YJ, Oh CM, Kong HJ, Lee DH, Lee KH, et al. Cancer statistics in Korea: incidence, mortality, survival, and prevalence in 2014. Cancer Res Treat 2017;49(2):292-305.

10. Jung KW, Shin HR, Kong HJ, Park S, Won YJ, Choi KS, et al. Long-term trends in cancer mortality in Korea (1983-2007): a joinpoint regression analysis. Asian Pac J Cancer Prev 2010; 11(6):1451-1457.

11. Kim YA, Oh IH, Yoon SJ, Kim HJ, Seo HY, Kim EJ, et al. The economic burden of breast cancer in Korea from 2007-2010. Cancer Res Treat 2015;47(4):583-590.

12. Schnipper LE, Meropol NJ, Brock DW. Value and cancer care: toward an equitable future. Clin Cancer Res 2010;16(24):60046008.

13. Ljung R, Peterson S, Hallqvist J, Heimerson I, Diderichsen F. Socioeconomic differences in the burden of disease in Sweden. Bull World Health Organ 2005;83(2):92-99.

14. Savage $P$, Mahmoud S. Development and economic trends in cancer therapeutic drugs: a 5-year update 2010-2014. Br J Cancer 2015;112(6):1037-1041.

15. Farmer P, Frenk J, Knaul FM, Shulman LN, Alleyne G, Armstrong $\mathrm{L}$, et al. Expansion of cancer care and control in countries of low and middle income: a call to action. Lancet 2010; 376(9747):1186-1193.

16. Steenland K, Armstrong B. An overview of methods for calculating the burden of disease due to specific risk factors. Epidemiology 2006;17(5):512-519.

17. Kim EJ, Yoon SJ, Jo MW, Kim HJ. Measuring the burden of chronic diseases in Korea in 2007. Public Health 2013;127(9): 806-813.

18. Suh M, Choi KS, Park B, Lee YY, Jun JK, Lee DH, et al. Trends in cancer screening rates among Korean men and women: results of the Korean National Cancer Screening Survey, 20042013. Cancer Res Treat 2016;48(1):1-10.

19. Løberg M, Lousdal ML, Bretthauer M, Kalager M. Benefits and harms of mammography screening. Breast Cancer Res 2015; 17:63.

20. Gøtzsche PC, Jørgensen KJ. Screening for breast cancer with mammography. Cochrane Database Syst Rev 2013;(6):CD00
1877.

21. Bae JM. Overdiagnosis: epidemiologic concepts and estimation. Epidemiol Health 2015;37:e2015004.

22. Bae JM. Epidemiological evidences on overdiagnosis of prostate and kidney cancers in Korean. Epidemiol Health 2015;37: e2015015.

23. Welch HG, Black WC. Overdiagnosis in cancer. J Natl Cancer Inst 2010;102(9):605-613.

24. Bae JM. It needs adaptation to the 2015 Korean guideline for breast cancer screening. J Korean Med Assoc 2015;58(9):833837 (Korean).

25. Jameson JL, Longo DL. Precision medicine: personalized, problematic, and promising. N Engl J Med 2015;372(23):22292234.

26. Carlson RW, Allred DC, Anderson BO, Burstein HJ, Carter WB, Edge $S B$, et al. Breast cancer. Clinical practice guidelines in oncology. J Natl Compr Canc Netw 2009;7(2):122-192.

27. Studdert DM, Mello MM, Sage WM, DesRoches CM, Peugh J, Zapert K, et al. Defensive medicine among high-risk specialist physicians in a volatile malpractice environment. JAMA 2005; 293(21):2609-2617.

28. Earle CC, Landrum MB, Souza JM, Neville BA, Weeks JC, Ayanian JZ. Aggressiveness of cancer care near the end of life: is it a quality-of-care issue? J Clin Oncol 2008;26(23):3860-3866.

29. Brook RH. Assessing the appropriateness of care--its time has come. JAMA 2009;302(9):997-998.

30. Dalton WS, Sullivan DM, Yeatman TJ, Fenstermacher DA. The 2010 Health Care Reform Act: a potential opportunity to advance cancer research by taking cancer personally. Clin Cancer Res 2010;16(24):5987-5996.

31. Bae JM. Value-based medicine: concepts and application. Epidemiol Health 2015;37:e2015014.

32. Bae JM. Development and application of patient decision aids. Epidemiol Health 2015;37:e2015018.

33. Bae JM. Academic strategies based on evidence-practice gaps. Hanyang Med Rev 2015;35(1):3-8 (Korean).

34. Fujimori M, Uchitomi Y. Preferences of cancer patients regarding communication of bad news: a systematic literature review. Jpn J Clin Oncol 2009;39(4):201-216.

35. Grunfeld E, Folkes A, Urquhart R. Do available questionnaires measure the communication factors that patients and families consider important at end of life? J Clin Oncol 2008;26 (23):3874-3878.

36. Pollak KI, Arnold RM, Jeffreys AS, Alexander SC, Olsen MK, Abernethy AP, et al. Oncologist communication about emotion 
during visits with patients with advanced cancer. J Clin Oncol 2007;25(36):5748-5752.

37. McFarlane J, Riggins J, Smith TJ. SPIKE\$: a six-step protocol for delivering bad news about the cost of medical care. J Clin Oncol 2008;26(25):4200-4204.

38. Meropol NJ, Schrag D, Smith TJ, Mulvey TM, Langdon RM Jr, Blum D, et al. American Society of Clinical Oncology guidance statement: the cost of cancer care. J Clin Oncol 2009;27(23): 3868-3874.

39. Brown MM, Brown GC, Sharma S, Landy J. Health care economic analyses and value-based medicine. Surv Ophthalmol 2003;48(2):204-223.

40. Brown MM, Brown GC, Sharma S, Stein JD, Roth Z, Campanella J, et al. The burden of age-related macular degeneration: a value-based analysis. Curr Opin Ophthalmol 2006;17(3):257266.

41. Neumann PJ, Palmer JA, Nadler E, Fang C, Ubel P. Cancer therapy costs influence treatment: a national survey of oncologists. Health Aff (Millwood) 2010;29(1):196-202.

42. Lenz M, Buhse S, Kasper J, Kupfer R, Richter T, Mühlhauser I. Decision aids for patients. Dtsch Arztebl Int 2012;109(22-
23):401-408.

43. Trevena LJ, Zikmund-Fisher BJ, Edwards A, Gaissmaier W, Galesic M, Han PK, et al. Presenting quantitative information about decision outcomes: a risk communication primer for patient decision aid developers. BMC Med Inform Decis Mak 2013;13 Suppl 2:S7.

44. Stacey D, Légaré F, Lewis K, Barry MJ, Bennett CL, Eden KB, et al. Decision aids for people facing health treatment or screening decisions. Cochrane Database Syst Rev 2017;4:CD001431.

45. O'Connor AM, Llewellyn-Thomas HA, Flood AB. Modifying unwarranted variations in health care: shared decision making using patient decision aids. Health Aff (Millwood) 2004;Suppl Variation:VAR63-VAR72.

46. Döring AC, Hageman MG, Mulder FJ, Guitton TG, Ring D; Science of Variation Group, et al. Trigger finger: assessment of surgeon and patient preferences and priorities for decision making. J Hand Surg Am 2014;39(11):2208-2213.e2.

47. O'Connor AM, Wennberg JE, Legare F, Llewellyn-Thomas HA Moulton BW, Sepucha KR, et al. Toward the 'tipping point': decision aids and informed patient choice. Health Aff (Millwood) 2007;26(3):716-725. 


\title{
Strategies for Appropriate Patient-centered Care to Decrease the Nationwide Cost of Cancers in Korea
}

\author{
Jong-Myon Bae \\ Department of Preventive Medicine, Jeju National University School of Medicine, Jeju, Korea
}

\section{국가 암 비용 감소를 위한 환자중심 진료의 적정성 확보 전략}

\section{배종면}

제주대학교 의학전문대학원 예방의학교실

In terms of years of life lost to premature mortality, cancer imposes the highest burden in Korea. In order to reduce the burden of cancer, the Korean government has implemented cancer control programs aiming to reduce cancer incidence, to increase survival rates, and to decrease cancer mortality. However, these programs may paradoxically increase the cost burden. For examples, a cancer screening program for early detection could bring about over-diagnosis and over-treatment, and supplying medical services in a paternalistic manner could lead to defensive medicine or futile care. As a practical measure to reduce the cost burden of cancer, appropriate cancer care should be established. Ensuring appropriateness requires patient-doctor communication to ensure that utility values are shared and that autonomous decisions are made regarding medical services. Thus, strategies for reducing the cost burden of cancer through ensuring appropriate patient-centered care include introducing value-based medicine, conducting cost-utility studies, and developing patient decision aids.

Key words: Tumor burden, Cost of illness, Medical practice, Quality of health care, Practice valuation and purchase, Decision support techniques

\section{서론}

한 국가에 있어 각종 질병부담(burden of disease)의 수준 을 측정하고 그 추세(trends)를 알아보는 것은, 국민의 건강 수준 향상을 추구하는 국가 보건사업 정책의 결정과 수행 에 주요한 근거가 된다[1]. 더군다나 전 세계적으로 국가별 보건의료의 비용 상승에 대한 압박을 받으면서[2], 국가별 로 한정된 의료자원을 효율적으로 분배하기 위하여 질병 부담을 의사결정의 중요한 기준으로 삼고 있다[3].

지금까지 질병부담의 측정을 위해 제시된 방법은 (1) 고전 적 역학지표를 활용하는 법, (2) 비용 부담(cost burden)을 측 정하는 법, (3) 건강관련 삶의 질(health-related quality of life, HRQoL)을 고려한 측정법으로 대분할 수 있다[4]. 이중 HRQoL에 있어서 세계보건기구가 주축이 되어 Disability Ad- justed Life Year (DALY)란 지표를 개발하여 지속적으로 국제 질병 부담연구(Global burden of disease)를 수행하고 있다[5].

한국인에 있어 DALY를 기준으로 질병부담이 가장 높은 질환은 2002년 당시 암(cancer)이었으며[6], 십년이 지난 2012년 현재 내분비 질환으로 변동이 있었다[7]. 그러나 상 실건강년수(years of life lost to premature mortality) 지표로 볼 때 암은 2012년에서도 여전히 1위를 차지하고 있다[7]. 이처 럼 적용하는 지표에 따라 질병부담의 해석에 차이가 있다 는 점에서, 생존율을 반영하는 사망/발생 비(mortality: incidence ratios, MIR)를 활용하자는 주장도 제기되고 있다[8].

따라서 암 부담을 감소시키려는 각종 정책들은 암발생 을 줄이고, 이미 발생한 환자에 있어서 생존율을 높여서 암 으로 인한 사망수준을 줄이는 것이라고 요약할 수 있다[8]. 그런데, 2002년과 2012년의 10년 사이에 암의 발생률, 사망 
Table 1. Indices of the overall cancer burden between 2002 and 2012 in Korea'

\begin{tabular}{lcc}
\hline & $\mathbf{2 0 0 2}$ & $\mathbf{2 0 1 2}$ \\
\hline DALY [3,5] & 1525 & 2261 \\
Incidence [9] & 229.8 & 323.3 \\
Mortality [10] & 149.0 & 131.3 \\
\hline
\end{tabular}

DALY, disability-adjusted life years.

'DALY: per 100000 population; Age-adjusted Incidence and mortality: per 100000 population.

률, DALY 변동을 살펴보았을 때, 사망률이 감소했지만 발 생률과 DALY는 오히려 증가했다는 점에서 암 부담 지표 개 선 노력에 대한 재고가 필요하다(Table 1). 예를 들어 암 부 담 감소의 일환으로 시행되는 조기암 검진사업은 암의 유 병률을 높이면서 암 치료 비용에 있어 오히려 경제적 부담 을 증가시킬 수 있다[11-14]. 이런 모순 속에 경제적 부담을 암 부담의 또 다른 지표로 다룰 필요도 있다[13].

본 논고의 목적은 암 부담을 감소시키려는 각종 노력들 이 암 부담과 관련한 지표들의 변동만이 아니라 암질환의 비용부담도 감소시키는 가를 살펴보고, 특히 보건의료 서 비스의 소비자인 환자 중심으로 암 진료의 적정성 확보를 통해 암 비용을 감소시킬 수 있는 전략적 방안들을 제시하 는 것이다.

\section{암관련 통계지표에 근거한 암부담 감소 정책의 실제적 영향}

\section{1. 발생률 감소}

암 부담의 감소를 위해 암 발생을 예방하는 것은 아무리 강조해도 지나치지 않다[15]. 암 발생에 관련한 위험 요인 (risk factor)의 기여분율(attributable fraction)을 산출하고 [16], 그 결과에 근거하여 일차 암예방 사업의 우선순위를 정해서 위험 요인들을 감소시키는 노력은 지속적으로 이 루어져야 한다[17]. 한국인에 있어 2012년부터 암 발생률이 감소하고 있다는 점은 국가 차원의 암 부담 수준을 낮추는 고무적인 사실이다[9].

\section{2. 완치율 향상}

일단 발생이 시작된 암에 대하여는 완치율을 높이는 것 이 암 부담 감소를 시키는 것이 된다. 완치율을 높이는 전략 으로 (1) 조기에 진단을 하거나, (2) 효과적인 의료서비스를 제공하는 것이다.

첫째 전략인 국가암검진 사업(National Cancer Screening Program in Korea, NCSP)은 1999년을 시작으로 검진 대상 원 발암을 확대하여 2016년 현재 5대 주요 원발암 -위암, 간암,
대장직장암, 유방암, 자궁경부암-에 대하여 성인을 대상으 로 시행하고 있다[18]. 2012-2014년도 발생률 변화에 있어 유방암을 제외한 나머지 4 개 암의 발생률이 감소 추세를 보 였다는 점[9]과 전체 암사망률이 1983-2002년까지는 증가 했다가 2002-2007년에 감소했다는 점은 NCSP의 긍정적 영 향으로 설명할 수 있다[10]. 그렇지만 NCSP 사업에 있어 다 각도의 비용분석(cost analysis) 연구가 이루어 져야만 보다 정확한 추론이 가능하다.

한편 NCSP의 검진항목에 포함된 유방암의 발생률이 지 속적으로 상승했다는 점은 조기검진의 과진단(over-diagnosis) 논란과 연계해서 살펴볼 필요가 있다[19,20]. 유방암 은 갑상선암, 전립선암, 신장암과 함께 과진단을 일으키는 대표 암종이기 때문이다[21,22]. 과진단은 곧 과치료(overtreatment)를 야기하고, 의료서비스를 오남용하는 결과를 초래한다는 점에서, 이들 암에 대한 조기진단의 노력은 오 히려 암 부담을 증가시키는 모순을 낳게 만든다 $[11,23]$. 그 렇기에 현재 NCSP 사업의 검사 항목에 유방암을 포함하는 것을 재고할 필요가 있다[24]. 반면에 조기검진의 효과가 입증된 암종에 대하여만 검진을 할 때, 암 부담 감소란 목적 을 달성할 수 있는 것이다[10].

둘째 전략인 효과적인 의료를 제공하려는 노력의 일환 으로 최근에는 개별 환자의 암 유전형에 맞춘 항암제를 투 여하는 맞춤의학(personalized medicine) 혹은, 정밀의학 (precision medicine)이 대두되고 있다[25]. 이처럼 의료기술 개발에 의해 암 치료 비용이 크게 상승하고 있지만, 비용 대 비 효과에 대한 의사결정용 근거가 빈약한 것이 현실이다 [2,14]. 즉, 진료 현장에서 비용부담보다는 치료 효과를 더 강조한 흐름 속에, 암 치료의 비용 부담이 증가하고 있는 것 이다[11,12].

또한 치료율을 높일 경우 암 유병률이 높아지면서, 장애 손실연수(years lived with disability)가 높아져 암부담을 증가 시키는 요소가 된다[26]. 따라서 완치율을 향상시키려는 다 각도의 노력은 조기검진의 효과가 입증된 암종에 대한 검 진사업을 제외하고는 나머지 모두다 암 비용부담을 실제 적으로 증대시킬 수 있다.

\section{3. 사망률 감소}

암 진단이후 치료를 했지만 완치를 할 수 없는 경우뿐만 아니라, 완치가 되었다고 해도 그 이후 재발 가능성이 있는 암환자에 있어서, 조기 사망을 줄여서 생존율을 높이는 것 은 암 부담 감소에서 중요하다. 그러나 암 진료현장에서 생 존율을 높이기 위한 노력에서, 방어진료(defensive medicine) 와무의미한 연명치료(futility)가 이루어 질 수 있다.

방어 진료는 의료과실(medical malpractice)에 대한 대비 를 위하여 불필요한 의료서비스를 행하는 것으로[27], 이는 


\section{Journal of}

곧 의료비의 상승과 의료보험의 재정 위기를 초래하여 암 비용 부담을 증대 시키는 중요한 요인이 된다[12,27]. 말기 암 환자에 있어 연명치료도 사망 일자를 늦추기 위하여 불 필요하게 치료비용을 증가시키게 한다[28].

\section{실제적인 암 비용부담 감소를 위한 제언: 환자중심의 진료 적정성(appropriateness) 확보}

이상에서 암 부담의 감소를 위해 3 가지 지표의 변화 -발 생률 감소, 완치율 향상, 사망률 감소-를 추구하는 노력은, 위험요인을 관리하여 발생률을 감소시키려는 것을 제외하 고는 오히려 암 치료비용을 증대시켜 실제적으로는 암 비 용부담을 증대시킬 수 있음을 살펴보았다. 반면 조기검진 의 효과가 있는 암종에 대한 검진사업은 암 부담을 실제로 감소시킬 수 있다는 점에서, 앞서 두 가지 지표-완치율 향 상과 사망률 감소-의 변화 노력에서 실제적으로 암 부담을 줄이기 위하여 의료서비스 소비자 환자, 제공자 의료인, 그 리고 정책 담당자의 3 자간 다각적인 전략들을 강구해야 한 다[29,30].

특히 암 진료비의 상승에 따른 암 비용부담 증대를 감축 하기 위해서는 보다 효율적이면서 효과적인 치료(more efficient and effectiveness care)를 해야 하는데, 이는 곧 의료 서비 스 제공의 적정성(appropriateness)을 실현하는 것이다[29]. 진료에 있어 적정성 확보를 위한 실천적 추진을 위하여 Brook [29]은 의료진과 환자 간의 가치(value)를 공유하여서, 의료서비스 선택에 있어 자율적 결정을 할 수 있어야 한다 고 주장하였다. 그의 주장을 수용하려면 (1) 환자-의사간수 평적 소통 관계를 형성할 수 있어야 하고, (2) 다양한 소통 도 구들을 이용하여 의료진의 적절한 설명에 환자가 충분히 이해하면서, 상호간 가치의 간극(gap)을 줄일 수 있어야 하 며, (3) 이런 상황 속에서 환자는 자신이 제공받을 의료 서비 스를 능동적으로 결정할 수 있도록 하는 것이다[30-33]. 이 렇게 되어야만 방어 진료나 무의미한 연명치료 같이 암 비 용부담을 오히려 증가시키는 모순에서 벗어날 수 있는 것 이다. 이상의 진료의 적정성을 확보하기 위한 3 가지 추진 요구들 각각에 있어 구체적인 수행 방안들은 다음과같다.

\section{1. 환자-의사 간 소통 구축을 위한 역량 강화}

암 진료에 있어 환자-의사 간 소통(patient-physician communication)은 무엇보다도 중요하다[34]. 환자에게 절망적 인 암 확진 사실을 알려주어야 하고, 암 치료로 인한 비용부 담이 생기기 때문이다[35]. 따라서 주치의 입장에서 성공적 인 신뢰 관계를 구축할 수 있는 실행 지침 등을 개발해서 이 를 적극 활용해야 한다[36]. 이와 관련하여 SPIKE\$ 란 protocolo이 제시되어 있는데[37], 국내 진료환경에 맞게 번안하
여 실제 활용할 필요가 있다.

또한 젊은 환자일수록, 여성 환자일수록, 교육수준이 높 을수록 환자-의사 간 소통을 더 요구한다는 점에서[34], 환 자 맞춤별로 소통의 폭을 달리할 수 있는 역량을 의료진들 이 갖출수 있도록 교육과정을 개발할 필요도 있다[38].

소통과정을 통해 의료진은 환자에게 최선의 근거(best evidences)에 따라 개발된 임상진료지침(clinical practice guideline, $\mathrm{CPG}$ )의 내용을 우선적으로 전달해야 한다[33]. 그러나 실제 진료현장은 $\mathrm{CPG}$ 를 적용하기가 용이하지 않다. 그 이 유로는 의학적 근거가 부족하거나, 환자 개개인이 바라는 의료서비스 요구 수준이 다르기 때문이다[31,38]. 근거가 부 족한 경우는 추가적인 연구를 수행하여 해결할 수 있지만, 개별 요구수준이 다른 경우에는 다음 단계로 환자의 선호 도를 알아낸 다음 비용에 따른 진료성과의 득과 실을 설명 할 수 있어야 한다[12]. 이 과정을 소홀히 할 때 방어 진료나 무의미한 연명치료 등이 개입되는 것이다 $[27,28]$.

\section{2. 환자의 선호도를 알아낼 가치평가 도구 개발}

환자의 선호도(preference)를 알아내는 노력은 곧 가치중 심의학(value-based medicine)을 실현하는 것이다[31]. 환자 의 선호도는 효용(utility) 개념과 연결되고, 효용 개념은 예 상되는 득과 실을 검토하여 의사결정 과정에 반영되기 때 문이다[39].

환자의 효용가치를 도출하기 위하여 시간교환법(time trade-off)을 가장 많이 사용하고 있는데, 환자가 이해하기 쉽고, 재현성이 높다는 장점 때문이다[40]. 이 측정법을 활 용하여 국내 암 환자의 상황에 맞게 비용-효용분석(costutility analysis)을 할 수 있는 측정도구 개발이 활발히 이루 어져야 한다[31]. 그래야만 암 진료의 비용 대비 효용을 극 대화하는 선택을 할 수 있어, 암 비용부담을 실제적으로 감 소시킬 바탕을 마련할수 있기 때문이다[41].

\section{3. 환자의 자율적 의사결정을 도울 도구 개발}

의료서비스의 소비자인 환자가 의사결정을 자율적으로 하려면 서비스 제공자인 의료진과 원활한 소통을 이룰 수 있는 신뢰 관계를 확보해서 주치의로부터 최선의 근거에 바탕한 충분한 설명이 이루어 진 다음, 환자 자신의 선호도 를 객관적으로 평가할수 있어야한다[38].

이렇게 환자가 처한 상황을 스스로 이해하고, 당사자의 선호도를 객관적으로 평가하면서 자율적인 의사결정을 할 수 있도록 환자결정 조력도구(patient decision aids, PDA)가 개발되고 있다[32,42]. 그 예로 과진단의 논란이 되고 있는 전립선암 조기검진용 검사를 할 것인가에 대하여 스스로 판단할 수 있는 도구가 개발되었으며[43], 이를 활용해서 조기검진용 검사를 $13 \%$ 줄일 수 있었다[44]. 이처럼 PDA를 
이용하여 의료서비스 소비자가 스스로 결정할 경우, 방어 진료 같이 의료자원을 낭비하는 것을 줄일 수 있으면서 $[45,46]$, 보건의료의 질적 향상도 도모할 수 있는 것이다 $[38,47]$.

결론

따라서 암 진료의 적정성을 확보하기 위해서는 환자-의 사 소통을 할 수 있도록 의료진의 역량을 강화시킬 행동 지 침서를 개발하고 교육하며, 환자의 효용가치를 측정할 수 있는 측정도구들을 적극 개발해야 하며, 최선의 근거와 효 용가치에 따라 환자 스스로 의사결정을 자율적으로 할 수 있는 $\mathrm{PDA}$ 를 개발하는 것이 핵심이다. 이를 통해 암 환자와 그 가족, 나아가 국가의 암 비용부담을 줄일 수 있을 것이다.

\section{감사의 글}

이 논문은 2017학년도 제주대학교 학술진흥연구비 지원 사업에 의하여 연구되었음.

\section{참고문헌}

1. Williams A. Calculating the global burden of disease: time for a strategic reappraisal? Health Econ 1999;8(1):1-8.

2. Meropol NJ, Schulman KA. Cost of cancer care: issues and implications. J Clin Oncol 2007;25(2):180-186.

3. Yoon SJ, Lee H, Shin Y, Kim Yl, Kim CY, Chang H. Estimation of the burden of major cancers in Korea. J Korean Med Sci 2002; 17(5):604-610.

4. Yoon SJ, Bae SC. Current scope and perspective of burden of disease study based on health related quality of life. J Korean Med Assoc 2004;47(7):600-602 (Korean).

5. Gong YH, Yoon SJ, Jo MW, Kim A, Kim YA, Yoon J, et al. The burden of cancer in Korea during 2012: findings from a prevalence-based approach. J Korean Med Sci 2016;31 Suppl 2: S168-S177.

6. Yoon SJ, Bae SC, Lee SI, Chang H, Jo HS, Sung JH, et al. Measuring the burden of disease in Korea. J Korean Med Sci 2007; 22(3):518-523.

7. Yoon J, Oh IH, Seo H, Kim EJ, Gong YH, Ock M, et al. Disabilityadjusted life years for 313 diseases and injuries: the 2012 Korean Burden of Disease Study. J Korean Med Sci 2016;31 Suppl 2:S146-S157.

8. Soerjomataram I, Lortet-Tieulent J, Ferlay J, Forman D, Mathers C, Parkin DM, et al. Estimating and validating disability-adjust- ed life years at the global level: a methodological framework for cancer. BMC Med Res Methodol 2012;12:125.

9. Jung KW, Won YJ, Oh CM, Kong HJ, Lee DH, Lee KH, et al. Cancer statistics in Korea: incidence, mortality, survival, and prevalence in 2014. Cancer Res Treat 2017;49(2):292-305.

10. Jung KW, Shin HR, Kong HJ, Park S, Won YJ, Choi KS, et al. Long-term trends in cancer mortality in Korea (1983-2007): a joinpoint regression analysis. Asian Pac J Cancer Prev 2010; 11(6):1451-1457.

11. Kim YA, Oh IH, Yoon SJ, Kim HJ, Seo HY, Kim EJ, et al. The economic burden of breast cancer in Korea from 2007-2010. Cancer Res Treat 2015;47(4):583-590.

12. Schnipper LE, Meropol NJ, Brock DW. Value and cancer care: toward an equitable future. Clin Cancer Res 2010;16(24):60046008.

13. Ljung R, Peterson S, Hallqvist J, Heimerson I, Diderichsen F. Socioeconomic differences in the burden of disease in Sweden. Bull World Health Organ 2005;83(2):92-99.

14. Savage $P$, Mahmoud S. Development and economic trends in cancer therapeutic drugs: a 5-year update 2010-2014. Br J Cancer 2015;112(6):1037-1041.

15. Farmer P, Frenk J, Knaul FM, Shulman LN, Alleyne G, Armstrong $L$, et al. Expansion of cancer care and control in countries of low and middle income: a call to action. Lancet 2010; 376(9747):1186-1193.

16. Steenland K, Armstrong B. An overview of methods for calculating the burden of disease due to specific risk factors. Epidemiology 2006;17(5):512-519.

17. Kim EJ, Yoon SJ, Jo MW, Kim HJ. Measuring the burden of chronic diseases in Korea in 2007. Public Health 2013;127(9): 806-813.

18. Suh M, Choi KS, Park B, Lee YY, Jun JK, Lee DH, et al. Trends in cancer screening rates among Korean men and women: results of the Korean National Cancer Screening Survey, 20042013. Cancer Res Treat 2016;48(1):1-10.

19. Løberg M, Lousdal ML, Bretthauer M, Kalager M. Benefits and harms of mammography screening. Breast Cancer Res 2015; 17:63.

20. Gøtzsche PC, Jørgensen KJ. Screening for breast cancer with mammography. Cochrane Database Syst Rev 2013;(6):CD00 1877.

21. Bae JM. Overdiagnosis: epidemiologic concepts and estimation. Epidemiol Health 2015;37:e2015004.

22. Bae JM. Epidemiological evidences on overdiagnosis of prostate and kidney cancers in Korean. Epidemiol Health 2015;37: 
e2015015.

23. Welch HG, Black WC. Overdiagnosis in cancer. J Natl Cancer Inst 2010;102(9):605-613.

24. Bae JM. It needs adaptation to the 2015 Korean guideline for breast cancer screening. J Korean Med Assoc 2015;58(9):833837 (Korean).

25. Jameson JL, Longo DL. Precision medicine: personalized, problematic, and promising. N Engl J Med 2015;372(23):22292234.

26. Carlson RW, Allred DC, Anderson BO, Burstein HJ, Carter WB, Edge SB, et al. Breast cancer. Clinical practice guidelines in oncology. J Natl Compr Canc Netw 2009;7(2):122-192.

27. Studdert DM, Mello MM, Sage WM, DesRoches CM, Peugh J, Zapert K, et al. Defensive medicine among high-risk specialist physicians in a volatile malpractice environment. JAMA 2005; 293(21):2609-2617.

28. Earle CC, Landrum MB, Souza JM, Neville BA, Weeks JC, Ayanian JZ. Aggressiveness of cancer care near the end of life: is it a quality-of-care issue? J Clin Oncol 2008;26(23):3860-3866.

29. Brook RH. Assessing the appropriateness of care--its time has come. JAMA 2009;302(9):997-998.

30. Dalton WS, Sullivan DM, Yeatman TJ, Fenstermacher DA. The 2010 Health Care Reform Act: a potential opportunity to advance cancer research by taking cancer personally. Clin Cancer Res 2010;16(24):5987-5996.

31. Bae JM. Value-based medicine: concepts and application. Epidemiol Health 2015;37:e2015014.

32. Bae JM. Development and application of patient decision aids. Epidemiol Health 2015;37:e2015018.

33. Bae JM. Academic strategies based on evidence-practice gaps. Hanyang Med Rev 2015;35(1):3-8 (Korean).

34. Fujimori M, Uchitomi Y. Preferences of cancer patients regarding communication of bad news: a systematic literature review. Jpn J Clin Oncol 2009;39(4):201-216.

35. Grunfeld E, Folkes A, Urquhart R. Do available questionnaires measure the communication factors that patients and families consider important at end of life? J Clin Oncol 2008;26 (23):3874-3878.

36. Pollak KI, Arnold RM, Jeffreys AS, Alexander SC, Olsen MK, Abernethy AP, et al. Oncologist communication about emotion during visits with patients with advanced cancer. J Clin Oncol
2007;25(36):5748-5752.

37. McFarlane J, Riggins J, Smith TJ. SPIKES: a six-step protocol for delivering bad news about the cost of medical care. J Clin Oncol 2008;26(25):4200-4204.

38. Meropol NJ, Schrag D, Smith TJ, Mulvey TM, Langdon RM Jr, Blum D, et al. American Society of Clinical Oncology guidance statement: the cost of cancer care. J Clin Oncol 2009;27(23): 3868-3874.

39. Brown MM, Brown GC, Sharma S, Landy J. Health care economic analyses and value-based medicine. Surv Ophthalmol 2003;48(2):204-223.

40. Brown MM, Brown GC, Sharma S, Stein JD, Roth Z, Campanella $J$, et al. The burden of age-related macular degeneration: a value-based analysis. Curr Opin Ophthalmol 2006;17(3):257266.

41. Neumann PJ, Palmer JA, Nadler E, Fang C, Ubel P. Cancer therapy costs influence treatment: a national survey of oncologists. Health Aff (Millwood) 2010;29(1):196-202.

42. Lenz M, Buhse S, Kasper J, Kupfer R, Richter T, Mühlhauser I. Decision aids for patients. Dtsch Arztebl Int 2012;109(2223):401-408.

43. Trevena LJ, Zikmund-Fisher BJ, Edwards A, Gaissmaier W, Galesic M, Han PK, et al. Presenting quantitative information about decision outcomes: a risk communication primer for patient decision aid developers. BMC Med Inform Decis Mak 2013;13 Suppl 2:S7.

44. Stacey $\mathrm{D}$, Légaré $\mathrm{F}$, Lewis $\mathrm{K}$, Barry MJ, Bennett $\mathrm{CL}$, Eden $\mathrm{KB}$, et al. Decision aids for people facing health treatment or screening decisions. Cochrane Database Syst Rev 2017;4:CD001431.

45. O'Connor AM, Llewellyn-Thomas HA, Flood AB. Modifying unwarranted variations in health care: shared decision making using patient decision aids. Health Aff (Millwood) 2004;Suppl Variation:VAR63-VAR72.

46. Döring AC, Hageman MG, Mulder FJ, Guitton TG, Ring D; Science of Variation Group, et al. Trigger finger: assessment of surgeon and patient preferences and priorities for decision making. J Hand Surg Am 2014;39(11):2208-2213.e2.

47. O'Connor AM, Wennberg JE, Legare F, Llewellyn-Thomas HA Moulton BW, Sepucha KR, et al. Toward the 'tipping point': decision aids and informed patient choice. Health Aff (Millwood) 2007;26(3):716-725. 